Aurora observed at Ovoca, Co. Wicklow, November 3.Observations from 5.30 p.m. to Midnight

AT $5.30 \mathrm{p} . \mathrm{m}$. yellow lights tinged with red were coming up all round the horizon; these at intervals formed indistinct columns to the south-west and north-west. At 6.30 there were faint reddlish lights forming fans at different points; these were succeeded by red and orange lights that rose forming glows, columns, and pencils; while at 7.30 a bright silver-white arch appeared to the north-the horns from this arch were pencils of white, which seemed to cross the arch; they were very numerous, appearing and disappearing nearly instantaneously ; from about four to seven appeared at one time. Some of them were very long, shooting up to the zenith. After the arch had dissolved away, brilliant narrow, well-defined, thin columns of silver light shot up, the most marked coming up to the north-west at 7.40 this darted up suddenly, and moved gradually southward, and when about due west, close to the church tower, it disappeared at 7.45 .

These silver lights solely occurred between the west and north. east, while all round the horizon red and orange lights were rising; these sometimes congregated at the zenith in a mass. At 7.50 two brilliant silver pencils rose to the north-north-east, but disappeared nearly instantaneously.

From 8 p.m. to 8.50 there were orange and red glows of light sometimes in indistinct columns; but at the latter hour there appeared to the north-west a vivid display of silver light that lasted about five minutes; this was succeeded by a deep orange cloud that travelled up to the zenith. From 9 to 10.30 there was an orange to red glow round the horizon, while at intervals from the north-west rose pencils of silver light, five very brilliant ones rising at 10.30. They were succeeded by a bright silver glow over the whole of the western heaven, across which at intervals passed glows of red and orange light; columns also rose, while at times horizontal streaks of brilliant silver lights appeared and disappeared in a flash. At I there was an orange glow round the horizon; this, with spurts of light coming up between the south-west and north-east, were all that was observed up to midnight. G. H. KinAHAN

\section{MR. SPENCER AND PROF. TAIT}

WHEN, in NATURE for July I 7 th, I 879, while reviewing Sir Edmund Beckett's book, Prof. Tait lugged in Mr. Kirkman's travesty of the definition of Evolution, most readers probably failed to see why he made this not very relevant quotation. But those who remembered a controversy which occurred some years previously, possibly divined the feeling which prompted him thus to go out of his way.

At the time I said nothing; but having recently had to prepare a new edition of "First Principles," and thinking it well to take some notice of books, and parts of books, that have been written in refutation of that work, I decided to deal also with Mr. Kirkman's implied criticism, in which Prof. Tait so heartily concurred; and by way of gauging Prof. Tait's judgment on this matter, I thought it not amiss to give some samples of his judgment on matters falling within his own department. To make it accessible to those possessing previous editions of "First Principles," the Appendix containing these replies to critics was published as a pamphlet.

In the inaugural lecture of this session, recently given to his students, part of which is published in the last number of NATURE, Prof. Tait first of all recalls a passage from the preceding controversy. From this he quotes, or rather describes, a clause which, standing by itself, appears sufficiently absurd; and he marks the absurdity by a double note of admiration. Whether when taken with its context it is absurd, the reader will be able to judge on reading the passage to which it belongs.

In disproof of certain conclusions of mine, there hat been quoted against me the dictum of Prof. Tait concerning the laws of motion, which is that - "as the properties of matter might have been such as to render a totally different set of laws axiomatic, these laws must be considered as resting on convictions drawn from observation and experiment and not on intuitive perception." Not urging minor objections to this dictum, I went on to say:- "It will suffice if I examine the nature of this proposition that 'the properties of matter might have been' other than they are. Does it express an experimentally-ascertained truth? If so, I invite Prof. Tait to describe the experiments? Is it an intuition? If so, then along with doubt of an intuitive belief concerning things as they are, there goes confidence in an intuitive belief concerning things as they are not. Is it an hypothesis? If so, the implication is that a cognition of which the negation is inconceivable (for an axiom is such) may be discredited by inference from that which is not a cognition at all, but simply a supposition. . . . I shall take it as unquestionable that nothing concluded can have a warrant higher than that from which it is concluded, though it may have a lower. Now the elements of the proposition before us are these :- $A s^{6}$ the properties of matter might have been such as to render a totally different set of laws axiomatic' [therefore] 'these laws [now in force] must be considered as resting ... not on intuitive perception :' that is, the intuitions in which these laws are recognised, must not be held authoritative. Here the cognition posited as premiss, is that the properties of matter might have been other than they are ; and the conclusion is that our intuitions relative to existing properties are uncertain. Hence, if this conclusion is valid, it is valid because the cognition or intuition respecting what might have been, is more trustworthy than the cognition or intuition respecting what is!"

From which it is manifest that, when asking (of course ironically) whether this alleged truth was an experimentally-ascertained one, my purpose was partly to ennumerate and test all imaginable suppositions respecting the nature of Prof. Tait's proposition, and partly to show that he had affirmed something concerning the properties of matter which cannot be experimentally verified, and therefore which, by his own showing, he has no right to affirm.

The first example which, in my recent replies to criticisms, I have given of Prof. Tait's way of thinking, is disclosed by a comparison of his views concerning our knowledge of the universe as visible to us, and our knowledge of an alleged invisible universe. This comparison shows that :-

"He thinks that while no validity can be claimed for our judgments respecting perceived forces, save as experimentally justified, some validity can be claimed for our judgments respecting unperceived forces, where no experimental justification is possible."

Part of Prof. Tait's answer is that "the theory there developed [in the "Unseen Universe"] was not put forward as probable, its purpose was attained when it was shown to be conceivable." "To which I rejoin that whereas Prof. Tait said he found in this theory a support for certain theological beliefs, he now confesses that he found none; for if no probability is alleged, no support can be derived. The other part of his answer concerns the main issue. After pointing out that the argument of this work, "carried on in pursuance of physical laws established by converse with the universe we know, extends them to the universe we do not know," I had urged that if we have "no warrant for asserting a physical axiom save as a generalisation of results of experiments-if, consequently, where no observation or experiment is possible, reasoning after physical methods can have no place; then there can be no basis for any conclusion respecting the physical relations of the seen and the unseen universes," "since, by the definition of it, one term of the relation is absent." Prof. Tait's explanation is extremely startling. When following the discussion in the "Unseen Universe," throughout which the law of the Conservation of Energy and the Principle of Continuity are extended from the tangible and visible matter and motion around us to an 
unknown form of existence with which they are supposed to be connected, readers little thought that Prof Tait meant by this unknown form of existence his own mind. Yet this is all that he now names as the missing term of the relation between the seen universe and the unseen universe.

The second sample which I gave of Prof. Tait's views on matters pertaining to his own subject, concerned the nature of inertia, which he describes by implication as a positive force. Here I quoted Prof. Clerk Maxwell. To repeat his criticism in full would cause me to trespass on the pages of NATURE even more unduly than I must do. If, however, any reader turns to NATURE, July $3 \mathrm{rd}$, 1879, and reads the passage in question, he will be able to judge whether it is, or is not, a joke, and if a joke, at whose expense. Meanwhile, the essential question remains. Prof. Tait says that matter has "an innate power of resisting external influences." I, contrariwise, say that the assertion of such a power is at variance with established physical principles.

One further illustration of Prof. Tait's way of thinising was added. Quoting from a lecture given by him at Glasgow, for the purpose of dispelling "the widespread ignorance as to some of the most important elementary principles of physics," I compared two different definitions of force it contained. In a passage from Newton, emphatically approved by Prof. Tait, force is implied to be that which changes the state of a body, or, in modern language, does work upon it. Later on in the lecture, Prof. Tait says-"force is the rate at which an agent does work per unit of length." I contended that these definitions are irreconcilable with one another; and I do not see that Prof. Tait has done anything to reconcile them. True, he has given us some mathematics, by which he considers the reconciliation to be effected; and, possibly, some readers, awed by his equations, and forgetting that in symbolic operations, carried on no matter how rigourously, the worth of what comes out depends wholly on what is put in, will suppose that Prof. Tait must be right. If, however, his mathematics prove that while force is an agent which does work, it is also the rate at which an agent does work, then I say-so much the worse for his mathematics.

From these several tests of Prof. Tait's judgment, in respect to which I fail to see that he has clisposed of my allegations, I pass now to his implied judgment on the formula, or definition, of Evolution. And here I have first to ask him some questions. He says that because he has used the word "definition "instead of "formula," he has incurred my "sore displeasure and grave censure." In what place have I expressed or implied displeasure or censure in relation to this substitution of terms? Alleging that I have an obvious motive for calling it a "formula," he says I am "indignant at its being called a definition." I wish to see the words in which I have expressed my indignation; and shall be glad if Prof. Tait will quote them. He says- "It seems I should have called him the discoverer of the formula!" instead of "the inventor of the definition." Will he oblige me by pointing out where I have used either the one phrase or the other? These assertions of Prof. Tait are to me utterly incomprehensible. I have nowhere either said or implied any of the things which he here specifies. So far am I from consciously preferring one of these words to the other, that, until I read this passage in Prof. Tait's lecture, I did not even know that I was in the habit of saying "formula " rather than "definition." 'The whole of these statements are fictions, pure and absolute.

My intentional use of the one word rather than the other, is alleged by him $d$ propos of an incidental comparison I have made. To a critic who had said that the formula or definition of Evolution "seems at best rather the blank form for a universe than anything corresponding to the actual world about us," I had replied that it might similarly be "remarked that the formula -.." bodies attract one another directly as their masses and inversely as the squares of their distances,' was at best but a blank form for solar systems and sidereal clusters." Whereupon Prof. Tait assumes that I put the "Formula of Evolution alongside of the Law of Gravitation," in respect to the definiteness of the previsions they severally enable us to make; and he proceeds to twit me with inability to predict what will be the condition of Europe four years hence, as astronomers "predict the positions of known celestial bodies four years beforehand." Here we have another example of Prof. Tait's peculiarity of thought. Because two abstract generalisations are compared as both being utterly unlike the groups of concrete facts interpreted by them, therefore they are compared in respect to their other characters.

But now I am not unwilling to deal with the contrast Prof. Tait draws; and am prepared to show that when the conditions are analogous, the contrast disappears. It seems strange that I should have to point out to a scientific man in his position, that an alleged law may be pcrfectly true, and that yet, where the elements of a problem to be dealt with under it are numerous, no specific deduction can be drawn. Does not Prof. Tait from time to time teach his students that in proportion as the number of factors concerned in the production of any phenomenon becomes great, and also in proportion as those factors admit of less exact measurement, any prediction made concerning the phenomenon becomes less definite; and that where the factors are multitudinous and not measurable, nothing but some general result can be foreseen, and often not even that? Prof. Tait ignores the fact that the positions of planets and satellites admit of definite prevision, only because the forces which appreciably affect them are few ; and he ignores the fact that where further such forces, not easily measured, come in to play, the previsions are imperfect and often wholly wrong, as in the case of comets; and he ignores the fact that where the number of bodies affecting one another by mutual gravitation is great, no definite prevision of their positions is possible. If Prof. Tait were living in one of the globular star-clusters, does he think that after observations duly taken, calculations based on the law of gravitation wculd enable him to predict the positions of the component stars four years hence? By an intelligence immeasurably transcending the human, with a mathematics to match, such prevision would doubtless be possible; but considered from the human standpoint, the law of gravitation, even when uncomplicated by other laws, can yield under such conditions only general and not special results. And if Prof. Tait will deign to look into "First Principles," which he apparently prides himself on not having done, he will there find a sufficient number of illustrations showing that not only other orders of changes, but even social changes, are predictable in respect to their general, if not in respect to their special, characters.

There remains only to notice the opinion which Prof. Tait seems still to hold, that the verbal transformation which Mr. Kirkman has made in the formula or definition of Evolution, suffices to show its hollowness. Here I may be excused for repeating what I bave already said elsewhere, namely, that "We may conveniently observe the nature of Mr. Kirkman's belief, by listening to an imaginary addition to that address before the Literary and Philosophical Society of Liverpool, in which he first set forth the leading ideas of his volume; and we may fitly, in this imaginary addition, adopt the manner in which he delights.

"Observe, gentlemen," we may suppose him saying, "I have here the yolk of an egg. The evolutionists, using their jargon, say that one of its characters is 'homogeneity'; and if you do not examine your thoughts, perhaps you may think that the word conveys some idea. But now if I translate it into plain English, and say that 
one of the characters of this yolk is 'all-alikeness,' you at once perceive how nonsensical is their statement. You see that the substance of the yolk is not all-alike, and that therefore all-alikeness cannot be one of its attributes. Similarly with the other pretentious term 'heterogeneity,' which, according to them, describes the state things are brought to by what they call evolution. It is mere empty sound, as is manifest if I do but transform it, as I did the other, and say instead 'not-all-alikeness.' For on showing you this chick into which the yolk of the egg turns, you will see that 'not-all-alikeness' is a character which cannot be claimed for it. How can any one say that the parts of the chick are not-all-alike? Again, in their blatant language we are told that evolution is carried on by continuous 'differentiations'; and they would have us believe that this word expresses some fact. But if we put instead of it 'somethingelseifications' the delusion they try to practise on us becomes clear. How can they say that while the parts have been forming themselves the heart has been becoming something else than the stomach, and the leg something else than the wing, and the head something else than the tail? The like manifestly happens when for 'integrations' we read 'sticktogetherations' : what sense the term might seem to have, becomes obvious nonsense when the substituted word is used. For nobody dares assert that the parts of the chick stick together any more than do the parts of the yolk. I need hardly show you that now when I take a portion of the yolk between my fingers and pull, and now when I take any part of the chick, as the leg, and pull, the first resists just as much as the last-the last does not stick together any more than the first; so that there has been no progress in 'sticktogetherations.' And thus, gentlemen, you perceive that these big words which, to the disgrace of the Royal Society, appear even in papers published by it, are mere empty bladders which these would-be philosophers use to buoy up their ridiculous doctrines."

But though it is here, I think, made apparent enough that even when disguised in Mr. Kirkman's grotesque words, the definition of Evolution continues truly to express the facts, Prof. Tait shows no sign of changing his original opinion that Mr. Kirkman has made "an exquisite translation" of the definition. Nay, so charmed does he appear to be with Mr. Kirkman's feats of this nature, that he gires us another of them. One of two conclusions must be drawn. Prof. Tait either thinks that fallacies are disclosed by the aid of these cacophonous long words, or else the clatter of curious syllabic compounds greatly excites his sense of humour. In the last case we may infer that had he been one of that "Twelfth Night" party in which the Clown exclaims-"I did impeticos thy gratillity," he would have joined in Sir Andrew Aguecheek's applause.

HERBERT SPENCER

\section{NOTES ON THE GEOLOGY OF EAST-CENTRAL AFRICA}

THOUGH many travellers have now penetrated almost every part of Central Africa, and described the main geographical features, yet their accounts have been singularly barren in any reliable geological details. The Geographical Society, in its late expedition to the lake region, sought to remedy this want, and $\mathrm{I}$, as a student of that science, had the honour of being selected as geologist and assistant to Mr. Keith Johnston, the leader of the expedition.

After the lamentable death of Mr. Johnston, almost at the commencement of our journey, the entire work of the expedition fell into my inexperienced hands, and to perform that work conscientiously precluded all hope of anything but the most superficial geological research. The difficulties in the way were, as in all tropical countries, much increased by the luxuriance of the vegetation, which seldom leaves a rock uncovered and exposed to view.
Notwithstanding these obstacles to geological investigation, however, glimpses of the internal structure of the country traversed were here and there obtained, which I think may fairly be considered as shadowing forth the main general features of the geology of the Great Lake Region.

Let me briefly point these out in the order of their occurrence along our route to Nyassa and Tanganyika. The comparatively unbroken stretch of low-lying country which so markedly borders the East Coast of Africa is formed of two, if not three, raised beaches, elevated in recent times above the sea. They consist chiefly of brick-red sands and clays overlying coral rock. The former have been derived by denudation from the coast ranges, which, consisting of hornblende rocks and others containing a large amount of iron, easily account for the deep-red colour characterising these deposits. The sands are of value as containing the gum copal, of which our best varnishes are made. As the tree from which this gum has been derived is now almost extinct, it would seem that a considerable lapse of time has occurred since these deposits have been formed; but geologically they must be recent, as among the many insects that have been found imbedded in the copal none, as far as I am aware, are extinct. The Msandarusi, or gum copal tree, has evidently been restricted to the sea-coast, as neither it nor the gum has ever been found as yet in the interior.

In passing from these sands and clays we step over an immense gap in the geological record, of which no trace remains, as the rocks we next reach are evidently of carboniferous age. These occupy a variable strip along the base of the mountains, here and there rising into small hills and ranges.

They are found stretching from at least Mozambique to the Equator. On the Rovuma coal-beds are found. In the Rufigi valley there are red liver-coloured sandstones with pebbled beds and with interbedded lavas which in one curiously-shaped mountain near Behobeho produce a remarkable step-like appearance. These beds are horizontal, but beneath them are sandstones tilted by the intrusion of eruptive basalts, producing an unconformability which however is probably only local. Further north on the Unyanyembe road from Bogamoyo, and at the base of the mountain I observed on my return march compact beds of fossiliferous limestones, together with shales, \&c.

At Umba, a place north of Pangani, I also discovered limestone, which I believe is now being burnt by the Universities Mission Agents. The young geologist, Thornton, the companion of Baron von der Decken, observed this same formation around Mombas, which he noted as being exactly similar to the coal formation of the Zambesi. As no rocks of a later date have been found along the whole of the east coast from Mozambique to the Equator, we may safely infer that this part of the continent has been above water since Carboniferous times, and this inference is strengthened by natural history evidence.

We have now reached the base of the mountains, and again we are brought face to face with another great break in the series of events. From the Carboniferous sandstones and limestones we pass abruptly to highly metamorphosed rocks whose exact place in the geological series is as yet extremely problematical. These consist of the schists, gneiss, and hornblende rocks which form the mountain range that flanks the great Central Plateau extending from Abyssinia to the Cape.

In crossing this range we rose to a height of 7000 feet. We found the strike of the rocks to be north and south. They present every intermediate grade of variation from the most coarsely crystalline to those with the bedding still traceable. Indeed it would be somewhat difficult to point out any sharply-defined line of demarcation between the granites, which seem to predominate 